\title{
The Dakwah Movement of Kiai Muda in Eastern Indonesia: Study of Islamic Application and Islamization Models of As'adiyah
}

\author{
Muhammad Alwi HS*, Iin Parninsih**, M. Riyan Hidayat*** \\ UIN Sunan Kalijaga Yogyakarta, Indonesia. E-mail: muhammad.alwi@uin-suka.ac.id*, iin.parninsih@gmail.com**, \\ mrhidayat28@gmail.com ${ }^{* * *}$
}

\begin{abstract}
This article discusses the roles of kiai muda in offering the model of typical As'adiyah Islamic Boarding School and disseminating Islam to the Eastern part of Indonesia. Kiai muda are the descendants of ulama graduating from Ma'had Aly at Pesantren As'adiyah. The study aims to answer some fundamental questions as to what As'adiyah Islamic model and the process of Islamization conducted by kiai muda from As'adiyah. The results show that As'adiyah grounds itself on Ahlu Sunna wal Jama'ah school of thoughts that is brought by Imam Nawawi and other the proponents of Shafi'i school of thought. The orientation of Ahlu Sunna wal Jama'ah and the typical Shafi'i mazhab are well maintained and practiced both in the pesantren and the surrounding community. The teachings of this school of thought are well received by the people of Eastern part of Indonesia. Hence, by all means, this has highly influenced the practices of dakwah delivered by kiai muda.
\end{abstract}

Keywords: As'adiyah, kiai muda, dakwah, Islam, Islamization

\section{Gerakan Dakwah Kiai Muda di Indonesia Timur: Studi Model Penerapan Islam dan Islamisasi Khas As'adiyah}

\begin{abstract}
Abstrak
Artikel ini membahas peran kiai muda dalam menerapkan model Isam khas As'adiyah beserta menyebarkannya kepada masyarakat di Indonesia Timur. Di sini, kiai muda adalah mereka yang ditetapkan sebagai kiai melalui kaderisasi ulama pada jenjang Ma'had Aly di Pesantren As'adiyah. Rumusan masalah artikel ini adalah bagaimana model penerapan Islam As'adiyah? Bagaimana model Islamisasi oleh para kiai muda dari As'adiyah? Artikel ini merupakan penelitian lapangan dengan menggunakan metode deskripsianalitis terhadap data-data yang terkait tema kajian. Adapun hasil temuan artikel ini menyatakan bahwa As'adiyah memiliki paham Ahlu Sunna wal Jama'ah yang mengacu pada pandangan Imam Nawawi, dan bermazhab Syafi'i. Paham dan mazhab tersebut dijaga, dipelajari, diamalkan dan disebarkan, baik dalam lingkungan pesantren maupun ketika berdakwah kepada masyarakat. Penyebaran paham dan mazhab ini diterima dengan baik oleh masyarakat, yang terlihat berdasarkan bertahan dan berkembangnya penerimaan masyarakat atas dakwah-dakwah yang disampaikan oleh kiai muda Pesantren As'adiyah. Karena itu, dalam rangka menjaga dan menyebarkan model penerapan Islam yang Ahlu Sunna wal Jama'ah dan bermazhab Syafi'i di Indonesia Timur, maka gerakan dakwah kiai muda perlu didukung dan dikembangkan.
\end{abstract}

Kata Kunci: As'adiyah, kiai muda, dakwah, Islam, Islamisasi

* Naskah diterima September 2021, direvisi Oktober 2021, dan disetujui untuk diterbitkan November 202

Dialog, 44 (2), 2021, 139-151

https://jurnaldialog.kemenag.go.id,p-ISSN:0126-396X, e-ISSN:2715-6230

This is open access article under CC BY-NC-SA-License

(https://creativecommons.org/license/by-nc-sa/4.0/)

Dialog Vol. 44, No.2, Desember 2021

139 


\section{A. Pendahuluan}

Dalam bukunya, Zamakhsyari Dhofier membagi tiga klasifikasi seseorang disebut sebagai kiai, khususnya di wilayah Jawa. Pertama, gelar kiai diberikan kepada orang yang dinilai kramat. Kedua, gelar kiai diberikan kepada orang tua. Ketiga, gelar kiai diberikan kepada orang yang ahli tentang ajaran Islam dan memiliki atau menjadi pimpinan pesantren (Dhofier, 2011). Muhammad Adlin Sila dengan mengutip pandangan Yanwar Pribadi dalam bukunya, Islam, State and Society (2018), mengatakan bahwa kiai di Madura berbeda dengan di Jawa. Di Madura, seseorang dapat disebut kiai apabila memenuhi syarat, di antara yang utama, seperti harus berasal dari keluarga (nasab) kiai, harus memimpin sebuah pesantren, dan harus menjadi anggota Nahdlatul Ulama (NU). Dari sini, jika satu atau lebih dari syarat-syarat tersebut tidak dimiliki, seseorang tidak akan diakui sebagai kiai (Sila, 2019). Di Sulawesi Selatan, gelar kiai relatif lebih mudah diperoleh daripada di Madura dan Jawa, di antara alasannya adalah karena dapat ditempuh melalui program kaderisasi pada jenjang Ma'had Al-Dirasah Al-Islamiyah Al'Ulya (selanjutnya disingkat Ma'had Aly) di pesantren, sebagaimana dilakukan di Pesantren As'adiyah.

As'adiyah termasuk pesantren yang mempelopori adanya program kaderisasi ulama di Sulawesi Selatan. Dalam sejarahnya, program ini merupakan buah dari forum Haiatul Tahaful yang dipelopori oleh Anregurutta haji (Muhammad, 2017) atau AGH. Muhammad Yunus Martan pada masa kepemimpinannya di As'adiyah. Forum Haiatul Tahaful menghasilkan di antaranya adalah $M a^{\prime} h a d A l y$, yang diorientasikan untuk menghasilkan ulamaulama muda yang disebut sebagai "Kiai Muda" (KM). Tujuannya adalah meningkatkan pendidikan sekaligus menyebarkannya kepada masyarakat di Sulawesi Selatan (Idham, 2017). Pada perkembangannya, dakwah yang dilakukan oleh para kiai muda tersebut telah meliputi banyak wilayah di Sulawesi (Selatan, Barat, Tenggara, Utara) dan sebagian di Papua, yang biasanya disebut Indonesia Timur (Parninsih, 2020). Dalam dakwahnya tersebut, diindikasikan adanya model penerapan Islam khas As'adiyah yang tersebar, termasuk melakukan penyebaran Islam atau Islamisasi kepada masyarakat.

Paparan mengenai kiai muda di atas memperlihatkan peran penting dalam penyebaran Islam di Indonesia, terutama di wilayah timur. Hal ini yang luput diungkap, di antaranya, dalam buku yang berjudul Mosques and Imams: Everyday Islam in Eastern Indonesia (2021) yang dieditori oleh Kathryn $\mathrm{M}$ Robinson. Buku ini membahas peran penting Imam Masjid dalam membentuk model berislam di berbagai daerah (perkampungan), terutama di Indonesia Timur. Secara spesifik, tulisan Wahyudi Halim, "The Reproduction of Imam and Their Changing Rolers Within the Contemporary Muslim Community in Wajo, South Sulawesi, Indonesia" berfokus pada Pesantren As'adiyah, tetapi tidak membahas peran kiai muda dalam penyebaran Islam di Indonesia Timur. Padahal, kiai muda menjadi agen dakwah sekaligus penyambung ajaran Islam antara Imam Masjid dan ulama yang menjadi gurunya di Pesantren As'adiyah. Agus Muchsin mengatakan bahwa Kiai muda menjadi bagian penting dari upaya pesantren dalam mempertahankan sekaligus mengembangkan kepercayaan masyarakat terhadap pondok pesantren (Muchsin, 2016). Untuk itu, para kiai muda tersebut dibekali berbagai disiplin keilmuan dalam rangka menghadapi dan menjawab berbagai persoalan keagamaan di kalangan masyarakat. Dari sini, artikel ini mengkaji tentang gerakan dakwah yang dilakukan oleh kiai muda dari Pesantren As'adiyah, yang kemudian memperlihatkan kekhasan model penerapan Islam dan Islamisasi yang dilakukannya.

Kajian yang pernah membahas tentang kiai muda selalu dikaitkan langsung dengan program kaderisasi ulama dan atau Ma'had Aly. Dalam artikelnya, "Pola Pengkaderan Ulama di Sulawesi Selatan (Studi pada Program Ma'had Aly Pondok Pesantren As'adiyah Sengkang Kabupaten Wajo)" (2017), Idham memperlihatkan posisi 
penting kaderisasi ulama yang dilakukan oleh Pesantren As'adiyah sebagai upaya menjaga dan mengembangkan generasi keulamaan dari kalangan pesantren yang telah berlangsung lama di Mah'ad Aly. Ahmad Kamal dan Malauddin Abu Nawas dalam arikelnya, "Pelaksanaan Pengajian Halaqah dalam Pemahaman Keagamaan pada Ma'had Aly Pondok Pesantren As'adiyah Sengkang Kabupaten Wajo" (2019), memperlihatkan sistem halaqah sebagai model pembelajaran yang khas dilakukan di kalangan kiai muda di Pesantren As'adiyah. Dengan segala metode, bentuk, serta rujukan yang digunakan dalam pembelajaran halaqah tersebut, kemudian dijadikan dasar dalam berdakwah kepada masyarakat luas. Agus Muchsin dalam artikelnya, "Penerapan Manhaj terhadap Penguatan Fikih Kaderisasi Ulama Pondok Pesantren As'adiyah Sengkang" (2016), memperlihatkan peran penting Kiai di Pesantren As'adiyah, bahkan menentukan arah bentuk dan penerapan mazhab beserta referensi yang digunakan.

Banyak lagi kajian yang serupa dengan di atas, yang mengungkap tentang peran penting kiai muda dalam konteks Ma'had Aly atau dan program kaderisasi ulama di Pesantren As'adiyah. Namun, berbagai kajian yang ada belum membahas peran penting Kiai muda sebagai agen dalam menampilkan model penerapan Islam dan Islamisasi di kalangan masyarakat. Yang dimaksud dengan Islamisasi dalam artikel ini adalah penyebaran paham Islam khas As'adiyah kepada masyarakat. Dari sini, letak penting artikel ini adalah dalam rangka mengungkap model penerapan Islam As'adiyah sebagai salah satu model beragama yang khas, seperti halnya model penerapan Islam khas Nahdlatul Ulama, Muhammadiyah dan Wahabi. Upaya ini penting, paling tidak, untuk menunjukkan bahwa Islam di Indonesia tidaklah satu warna, tetapi beragam. Dengan demikian, dapat dibedakan sekaligus dipetakan posisi Islam versi As'adiyah. Saat yang sama, artikel ini juga akan menunjukkan bahwa para kiai muda memiliki peran dalam mengislamisasi masyarakat Indonesia Timur, yang telah berlangsung sejak kemunculan Islam awal di Sulawesi Selatan.

\section{B. Metode Penelitian}

Pertanyaan yang hendak dijawab dalam artikel adalah bagaimana model penerapan Islam As'adiyah? Serta bagaimana model dan proses Islamisasi oleh kiai-kiai muda dari As'adiyah? Untuk menjawab pertanyaan tersebut, artikel ini menggunakan metode deskripsi-analitis, yakni mendeskripsikan sekaligus menganalisis data-data yang diperoleh terkait isu yang dikaji. Dalam konteks ini, artikel ini merupakan kajian lapangan, yang menunjukkan bahwa data-data yang dideskripsikan sekaligus dianalisis adalah data-data yang diperoleh di lapangan, baik berupa wawancara dari pihak Pesantren As'adiyah seperti beberapa kiai muda, pengurus pesantren, maupun lainnya yang dinilai dapat memberikan informasi penting terkait tema yang dikaji. Sumber primer lainnya juga dapat diperoleh dari observasi sekaligus hasil dokumentasi langsung, seperti website resmi Pondok Pesantren As'adiyah. Adapun sumber pendukung diperoleh dari sumber-sumber tertulis seperti artikel jurnal, buku, maupun literatur lainnya yang membahas tema kajian, baik dari sisi dakwah, Islamisasi, Pesantren As'adiyah, kiai muda, Ma'had Aly maupun kaderisasi ulama, selama hal itu terkait kajian. Sumber-sumber yang ditemukan tersebut dideskripsikan sekaligus dianalisis sehingga mencapai temuan yang baru dan menjawab rumusan masalah artikel ini.

\section{Hasil dan Pembahasan \\ Pesantren As'adiyah sebagai Distributor Pendakwah}

Dalam sejarahnya, pesantren di Indonesia telah muncul sejak abad ke-16 (Dhofier, 1982), bahkan disinyalir telah muncul di era penyebaran Islam oleh Walisongo, sebagaimana yang didirikan oleh Syaikh Maulana Malik Ibrahim (Ismail, 2002). Pesantren memiliki peran yang sangat penting dalam kemunculan dan pengembangan keagamaan di Indonesia 
(HS, 2019). Hal ini bukan hanya karena pesantren menjadi lembaga pendidikan tertua di Indonesia, tetapi juga menjadi lembaga pendidikan khas (indigenous) Indonesia. Kekhasan inilah sehingga nama Pesantren, yang biasa disebut berasal dari kata santri yang menerima imbuhan pe-an (pe-santri-an) (Ziemak, 1986), tidak tepat jika diterjemahkan sebagai, misalnya, 'Boarding School' dalam versi bahasa Inggris, ataupun dalam bahasa asing lainnya, sebagaimana yang umum terjadi. Lebih jauh, sebagai lembaga dengan keislaman dan keindonesiaan yang khas, pesantren senantiasa menjaga nilai-nilai kenusantaraan, bergerak maju, dan beradaptasi dengan perkembangan zaman (Hamdan, 2020). Informasi dari Pangkalan Data Pondok Pesantren menyebutkan bahwa hingga tahun 2021, tercatat tidak kurang dari 28.194 pesantren dari seluruh daerah di Indonesia (http:// ditpdpontren.kemenag.go.id/pdpp/statistik diakses pada 29 Januari 2021)

Berbagai pesantren tersebut di atas umumnya di bawah naungan Nahdlatul Ulama, Muhammadiyah, dan lainnya. Dalam konteks ini, As'adiyah menjadi satu pesantren tersendiri yang sekalipun memiliki paham keagamaan Ahlu Sunna wal Jama'ah dan bermazhab Syafi'i (Arief, 2007), tetapi bukan bagian Nahdlatul Ulama, Muhammadiyah, ataupun Persis. Lebih jauh, As'adiyah menjadi pesantren pertama di Sulawesi Selatan (Halim, 2018), bahkan ia disebut sebagai pesantren tertua di Indonesia Timur, serta dikenal sebagai pesantren yang banyak melahirkan pendakwah ulung di Indonesia Timur (Mujahad, 2018). AGH. Muhammad As'ad, nama lengkapnya adalah Syeikh Al-Allamah Muhammad As'ad bin Muhammad Abdul Rasyid Al-Bugisy, sebagai pendiri Pesantren As'adiyah dikenal sebagai ulama yang keilmuannya setara dengan KH. Hasyim Asy'ari, pendiri Nahdlatul Ulama (Wawancara bersama Kiai Muda Ilham Nur, salah satu pengasuh Pesantren As'adiyah, 23 Desember 2020). Hingga tahun 2020, As'adiyah saat ini telah melahirkan cabang pesantren di berbagai belahan Indonesia sebanyak kurang lebih 500 pesantren (https:/ /asadiyahpusat.org/2013/09/19/sejarahasadiyah/, diakses pada 28 Desember 2020).

Mengenai sejarah lahirnya Pesantren As'adiyah, para peneliti terbagi menjadi dua pendapat mengenai cikal bakal kelahirannya. Pertama, pendapat yang mengatakan bahwa cikal bakal As'adiyah dimulai dari Madrasah Aliyah Islamiyah (MAI) sekitar tahun 1928-1930. Kedua, pendapat yang mengatakan bahwa cikal bakal As'adiyah jauh sebelum MAI, yakni dimulai dari kegiatan halaqah yang biasa dilakukan oleh AGH. Muhammad As'ad di rumahnya yang kemudian berlanjut di masjid Jami' Sengkang-Wajo (Pasanreseng, 1992; Kalsum, 2008; Abunawas dan Ilyas, 2017). Di sini, jika melihat pembentukan Pesantren As'adiyah berdasarkan tradisi keilmuan pimpinan pertamanya, yakni AGH. Muhammad As'ad, maka pada dasarnya Pesantren As'adiyah tidak dimulai dari MAI atau kegiatan halagah, sebagaimana disebutkan oleh dua pendapat di atas, tetapi dapat ditelusuri hingga ke Mekkah-Arab. Pendapat ini dapat disandarkan pada perjalanan keilmuan AGH. Muhammad As'ad yang banyak mengenyam ilmu dari halaqah-halaqah di berbagai masjid Mekkah. Pengalaman halaqah di masjid-masjid Mekkah mempengaruhi proses berpikir sekaligus proses pembentukan kegiatan halaqah yang dilakukan di Sengkang, baik di rumah AGH. Muhammad As'ad maupun di masjid Jami'. Hal ini senada dengan pandangan bahwa keilmuan yang berkembang oleh ulama Indonesia tidak lepas dari hasil transmisi keilmuan Islam-Timur Tengah yang dibawa dan disesuaikan pada konteks Indonesia (Fathurrahman, 2004).

Lebih jauh, berdirinya Pesantren As'adiyah ini dari proses halagah yang dilakukan oleh AGH. Muhammad As'ad di Mekkah-Arab tersebut diperkuat oleh adanya temuan Ahmad Kamal Malauddin Abu Nawas (2019) bahwa halaqah mempengaruhi pemahaman keagamaan santrinya, yang kemudian apa yang dipelajari dalam halaqah tersebut kemudian didakwahkan kepada masyarakat luas. 
Tidak hanya itu, Pondok Pesantren As'adiyah dikenal sebagai pesantren yang banyak melahirkan pendakwah ulung, yang kemudian tersebar di berbagai wilayah, terutama di Indonesia Timur (Muhajad, 2019). Dengan kekhasan ini, tidak heran jika banyak yang mengkaji Pesantren As'adiyah sebagai pesantren yang 'bernuansa' dakwah, baik dari sisi tokohnya (baca: kiai/ ulamanya) maupun dari sisi lembaga pesantrennya. Di sini dapat disebutkan misalnya yang dilakukan oleh M. Sabit yang berjudul "Gerakan Dakwah H. Muhammad As'ad Al-Bugisi" (2012), Wahyuddin Halim yang berjudul "As'adiyah Traditions: the Construction and Reproduction of Religious Authority in Contemporary South Sulawesi" (2015), Aguswandi yang berjudul "Kontribusi AGH. Muhammad As'ad terhadap Pengembangan Dakwah di Sengkang Kabupaten Wajo (Suatu Kajian Tokoh Dakwah)" (2018), dan lain sebagainya.

Kesan yang berorientasi dakwah ini terus berlanjut hingga saat ini, terlihat dalam Visi dan Misi sebagaimana yang tercatat, misalnya, dalam Visi dan Misi 2012-2017. Dalam visi di tahun ini di antaranya dikatakan bahwa kehadiran As'adiyah sebagai pesantren dan lembaga yang mengembangkan pendidikan sekaligus menyebarkan dakwah Islam. Sementara dalam misi dikatakan bahwa menjaga sekaligus mengembangkan As'adiyah sebagai lembaga pendidikan dan dakwah Islam yang mampu merespon berbagai kebutuhan masyarakat (Muhajad, 2019; Sabit, 2015). Lebih jauh, dakwah khas As'adiyah dapat ditemukan dalam beberapa bentuk, misalnya, halaqah (Bugis: Mangngaji Tudang), yaitu kegiatan belajar-mengajar tentang Islam, yang dilakukan di masjidmasjid di Wajo, yang telah dimulai oleh AGH. As'ad. Selain itu, tradisi dakwah lainnya berlangsung selama bulan Ramadhan yang dilakukan bersanding dengan pengiriman imam shalat tarawih ke berbagai wilayah (Halim, 2021). Lebih jauh, tradisi dakwah ini semakin marak sekaligus meluas terjadi ketika muncul kaderisasi ulama, yang disebut kiai muda(KM), pada jenjang Mah'ad Aly. Terkait program kaderisasi ulama ini dibahas lebih pada pembahasan selanjutnya.

\section{Program Kaderisasi Ulama pada Jenjang Ma'had Aly}

Sebelumnya telah dipaparkan mengenai sejarah ringkas serta posisi Pondok Pesantren As'adiyah. Di sana dilihat bahwa Pesantren As'adiyah disebut sebagai pesantren yang berorientasi kepada dakwah, demikian juga banyak yang menelitinya dalam konteks dakwah. Lebih jauh, posisinya sebagai pesantren yang menghasilkan ulama-ulama dakwah sebenarnya telah berlangsung lama, bahkan dilakukan sendiri oleh AGH. Muhammad As'ad, sebagai pendiri sekaligus pimpinan pesantren tersebut. Hal ini sebagaimana diungkap oleh beberapa penelitian yang telah disebutkan sebelumnya. Lebih jauh, upaya penyebaran dan gerakan dakwah tersebut kemudian membentuk satu program yang diorientasikan untuk menguatkan gerakan dakwah tersebut, program tersebut adalah kaderisasi ulama yang ditempuh ketika memasuki jenjang Ma'had Aly (setingkat dengan program Sarjana [S1]).

Seperti dikemukakan sebelumnya bahwa secara substansi, program kaderisasi ulama di Ma'had Aly ini telah muncul pertama kali pada era AGH. Muhammad Yunus Martan (lihat kiprah beliau dalam Abunawas dan Ilyas, 2017; Muktamar, 2019; dan Ilyas, 2020). Pada saat itu, tepatnya tahun 1966 di Sengkang, terbentuk Haiatul Takaful li Munadhamah al-Tarbiyah alIslamiyah, yang biasa diringkas menjadi Haiatul Takaful, yang merupakan forum koordinasi antar pondok pesantren yang didirikan oleh para alumni MAI/As'adiyah, yakni Pondok Pesantren As'adiyah Sengkang, Pondok Pesantren Darul Da' wah wal Irsyad, Pondok Pesantren Yatsrib Soppeng, dan Ma'had Hadis Biru Bone. Forum ini kemudian menghasilkan program kaderisasi ulama untuk jenjang Ma'had Aly, yang di dalamnya diorientasikan untuk menghasilkan ulama-ulama muda yang disebut sebagai "Kiai Muda" (KM), dengan 
tujuan untuk meningkatkan pendidikan sekaligus mendakwahkan ajaran Islam di Sulawesi Selatan (Idham, 2017).

Spesifik kepada Ma'had Aly di Pondok Pesantren As'adiyah, saat ini di bawah pimpinan direktur AG. Dr. H. Muhyidin Tahin, M. Th.I. Lebih jauh, dalam halaman website resminya dikatakan sebagai berikut (https://asadiyahpusat.org/pendidikan/mahadaly/ diakses pada 02 Agustus 2021):

Ma'had Aly As'adiyah Pusat Sengkang adalah sebuah lembaga pendidikan Islam yang setara dengan program sarjana (S1), Berdasarkan SK Direktur Jendral Pendidikan Islam No. 3002 Tahun 2016 tentang izin pendirian Ma'had Aly di Pondok Pesantren.

Lembaga ini menyelenggarakan pendidikan akademik dalam bidang penguasaan Ilmu Agama Islam (Tafaqquh Fiddin) berbasis kitab kuning dengan program Takhassus Tafisr wa Ulumu al-Tafsir.

Lebih jauh, di halaman tersebut juga dikatakan bahwa Ma'had Aly menjadi perguruan tinggi yang berfokus pada bidang ilmu agama Islam (tafaqquh fi al-din) dengan menjadikan kitab-kitab kuning, yakni kitab berbahasa Arab, sebagai patokan pembelajaran (https://asadiyahpusat.org/ pendidikan/mahad-aly/ diakses pada 02 Agustus 2021). Adapun Visi, Misi, dan Tujuan Ma'had Aly Pondok Pesantren As'adiyah adalah sebagai berikut:

Visi

Menjadi Ma'had Aly yang unggul dalam penyelenggaraan pendidikan, peduli terhadap nilai akhlak al-karimah, menjadi rujukan dalam pengembangan ilmu pengetahuan, teknologi dan berkontribusi dalam pelaksanaan dakwah.

Misi

1. Mengembangkan ilmu pengetahuan dalam bidang tafsir melalui proses kegiatan akademik

2. Mengembangkan ilmu pengetahuan melalui riset dan pengkajian ilmu pengetahuan yang bercirikan Alquran.
3. Menyiapkan generasi qur'ani yang berguna bagi masyarakat serta dapat memecahkan persoalan kehidupan masyarakat

Tujuan

1. Menghasilkan lulusan yang inovatif, memiliki keunggulan komparatif dan kompetitif.

2. Menghsilkan karya inovatif berbasis Alquran dengan menjunjung tinggi nilainilai akhlak al-karimah.

3. Terwujudnya Ma'had Aly sebagai pusat kajian keilmuan berbasis Alquran, kearifan lokal, budaya nasional, dan tuntutan global.

\section{Pemahaman Islam Kiai Muda As'adiyah}

Pada pembahasan sebelumnya, telah dibahas mengenai profil Pondok Pesantren As'adiyah, serta program kaderisasi ulama di jenjang Ma'had Aly. Kedua pembahasan tersebut memperlihatkan posisi Pesantren As'adiyah dari sisi dakwah, yang menunjukkan bahwa As'adiyah menjadi pesantren yang menghasilkan banyak pendakwah-pendakwah. Hal ini telah terjadi sejak awal sejarahnya. Dengan adanya program kaderisasi ulama, orientasi dakwah tersebut lebih marak ditemukan, bahkan dapat disebut lebih tersistematik dan terkoordinasi. Dalam konteks ini, hal penting yang mesti dipaparkan adalah model keislaman yang dianut oleh kiai muda As'adiyah tersebut, baik dalam konteks Pesantren As'adiyah secara umum, maupun secara spesifik pada Ma'had Aly. Pemahaman ini berangkat dari kenyataan bahwa As'adiyah sebagai pesantren yang sekalipun memiliki paham keagamaan Ahlu Sunnah wal Jama'ah (Arief, 2007), tetapi ia bukan bagian Nahdlatul Ulama, Muhammadiyah, ataupun PERSIS. Paham keagamaan Ahlu Sunnah wal Jama'ah dipilih dengan alasan bahwa ia paling tepat dalam keberagamaan di Indonesia, sebagaimana juga dalam konteks As'adiyah (As'ad, 2009).

Lebih jauh, paham keagamaan Ahlu Sunnah wal Jama'ah tersebut di atas dapat dirujuk kepada pendirinya, yakni AGH. Muhammad As'ad. Dalam penelitian disertasinya, Ilham dengan mengutip 
temuan dari Abdul Aziz Al-Bone (1994) dan Syamsuddin Arif (2007) mengatakan bahwa AGH. Muhammad As'ad memilih sekaligus mengembangkan paham Ahlu Sunnah wal Jama'ah tersebut dalam rangka menghasilkan umat yang bertakwa, berilmu, berakhlak mulia, serta memiliki rasa tanggungjawab terhadap perkembangan agama, bangsa, dan negara Republik Indonesia (Ilham, 2017). Ilham mengatakan bahwa paham Ahlu Sunnah wal Jama'ah yang dimiliki oleh AGH. Muhammas As'ad dapat ditemukan dalam tulisannya yang berjudul ma la yasa alMuslim jahlahu min mujmal aqaid Ahl alSunnah wa al-Jama'ah (Al-Bugisi, $1355 \mathrm{H}$ ) (AlBugisi, n.d.). Dalam tulisan tersebut, menurut Ilham, di antara bagian penting adalah bagian yang mengatakan bahwa Inilah kitab yang menjelaskan bahwa tidak dibenarkan seorang Muslim untuk tidak mengetahui akidah ahl al-sunnah wa al-jama'ah (Ilham, 2017).

Di bawah payung Ahlu Sunnah wal Jama'ah, AGH. Muhammad As'ad mendefinisikan Islam sebagai kepatuhan dalam menjalankan serta menerima ajarannya serta meyakininya sepenuh hati. Definisi ini diadopsi sekaligus dipengaruhi dari pemikiran Imam Nawawi, yang mengatakan bahwa "Orang mukmin adalah mereka yang percaya dengan sungguhsungguh dalam hatinya, dan tidak sedikitpun keraguan baginya tentang kebenaran ajaran Islam serta tunduk menerimanya dengan mengucapkan dua kalimat syahadat"(Ilham, 2017). Pemahaman seperti ini sekalipun nampak umum ditemui tetapi ini menjadi bukti karakter dasar AGH. Muhammad As'ad yang selalu sikap beragama yang mayoritas dijadikan rujukan bagi umat, terlebih lagi pemikiran ini disandarkan langsung oleh Imam Nawawi, seorang ulama paling terkemuka di Indonesia.

Dalam konteks fikih, AGH. Muhammad As'ad mengikuti mazhab syafi'i. Ilham mengatakan bahwa dilihat dari karyakaryanya, AGH. Muhammad As'ad sangat jelas mengikuti mazhab Syafi'i, misalnya dalam karyanya yang berjudul Nail al-
Ma'mul 'ala Nazm Sullam al-Ushul (Ilham, 2017). Menurut Ilham sekalipun AGH. Muhammad As'ad menganut mazhab Syafi'i, tetapi ia tidak termasuk pengikut yang fanatik pada mazhab dan golongannya. AGH. Muhammad As'ad termasuk ulama yang argumentatif dan akomodatif, menerima perbedaan pandangan dalam persoalan furu', menghargai pendapat orang lain, serta mengedepankan persatuan dan kesatuan umat (Ilham, 2017).

Paham keagamaan di atas, masih dipertahankan hingga saat ini, dan terlihat dalam berbagai praktik keagamaan oleh kiai-kiai di Pesantren As'adiyah. Di antara praktik keagamaan yang dimaksud adalah melaksanakan shalat Tarawih sebanyak 20 rakaat, membaca zikir tertentu, shalawatan, membaca Barazanji, qunut, dan lainnya (As'ad, 2009). Model penerapan Islam seperti ini dilakukan secara menyeluruh oleh berbagai elemen di Pondok Pesantren As'adiyah, bukan hanya dari kiai/ulama pimpinan, kiai muda, tetapi juga para santrisantrinya.

Adapun literatur yang menjadi rujukan pemahaman Islam dalam lingkungan Pesantren As'adiyah di antaranya adalah kitab Tafsir Jalalain (tafsir), kitab Riyadhushshalihin dan kitab Shahih AlBukhari (hadis), Tanwirul Qulub (tauhid), Fathul Muin, Irysadul 'Ibad, dan Al-Muhazzab (fikih), dan Kitab Mauidzahul Mu'minin (akhlak), dan Syarhul Hikam, (tasawwuf) (As'ad, 2009). Pemahaman Islam inilah yang kemudian disebarluaskan dalam dakwah kiai muda ke berbagai wilayah di Indonesia Timur.

\section{Gerakan Dakwah Kiai Muda dalam Islamisasi di Indonesia Timur}

Sebelumnya telah dijelaskan mengenai paham keagamaan yang dianut oleh kiai di Pesantren As'adiyah, baik yang dipegang oleh kiai pimpinan, kiai muda, ataupun dalam konteks santri secara keseluruhan, yang semuanya dapat dirunut dari paham keagamaan AGH. Muhammad As'ad sebagai pendiri pesantren tersebut. Dengan kata lain, sebagai pelanjut generasi 
kepesantrenan, tentu saja generasi-generasi setelah AGH. Muhammad As'ad juga meneruskan paham keagamaan tersebut, termasuk dalam hal ini pada masa kepemimpinan AGH. Muhammad Yunus Maratan dengan munculnya program kaderisasi ulama pada jenjang $M a^{\prime}$ had Aly yang menghasilkan kiai-kiai muda yang kelak menyebarkan atau menjadi penyambung lidah atas dakwah keagamaan guru-gurunya kepada masyarakat awam. Dalam konteks ini, penyebaran dakwah yang dilakukan oleh kalangan kiai muda As'adiyah tidak dapat dilepaskan dari jejak sejarah penyebaran dakwah yang dilakukan oleh ulama-ulama As'adiyah. Hal ini karena penerimaan dakwah dari kalangan kiai muda sebenarnya ikut dipengaruhi oleh masa lalu dakwah-dakwah yang disebarkan oleh para ulama sebelumnya, sehingga selaras dengan pengalaman masyarakat terhadap ulama-ulama tersebut. Dengan demikian, bagian ini memaparkan gerakan dakwah kiai muda dengan diawali oleh pembahasan sejarah dakwah ulama Pesantren As'adiyah.

Dalam catatan sejarah proses Islamisasi di Indonesia Timur, terutama di Sulawesi Selatan, baru terjadi sekitar abad $16 \mathrm{M}$, yang menunjukkan lebih lambat dibanding wilayah Nusantara lainnya (Azra, 1998). Proses Islamisasinya pun memiliki karakteristik tersendiri. Di berbagai wilayah, proses Islamisasi berjalan damai, hanya pada kerajaan wilayah Bone, Soppeng, dan Wajo (dikenal dengan aliansi tellupoccoe) yang mengalami perlawanan. Ketiga kerajaan tersebut menilai bahwa upaya Islamisasi yang dilakukan saat itu, oleh kerajaan Gowa-Tallo, merupakan siasat politik semata. Dalam artian, jika kerajaan Bone, Soppeng, dan Wajo tersebut masuk Islam, secara otomatis akan dihegemoni oleh kerajaan Gowa-Tallo. Ringkasnya, setelah mengalami berbagai dinamika politik, sosial, serta keagamaan, pada akhirnya kerajaan Bone, Soppeng, dan Wajo berhasil diislamkan (Akhmar, 2018). Di sini, masuknya raja-raja mereka ke dalam Islam juga menuntut masyarakat mereka untuk memeluk agama Islam (Ilham, 2017). Dalam konteks ini, Islamisasi yang muncul bukan berdasarkan pemahaman, kesadaran, dan pilihan individu tersendiri. Hal ini berakibat minimnya pemahaman dan pengetahuan keagamaan masyarakat mengenai agama baru mereka tersebut, yakni Islam.

Saat yang sama, masyarakat Sulawesi Selatan, hingga datangnya Islam, masih memegang erat adat istiadat atau norma kehidupan mereka, yang disebut dengan Pangngaderreng yakni aturan segala tingkah laku kehidupan manusia. Norma ini sebelumnya terdiri dari empat bagian, yakni Ade', bicara, rapang, dan wari, setelah Islamisasi, ada penambahan satu bagian, yakni sara' yaitu syariat Islam. Dari sini, adat yang dipegang dan dipertahankan oleh masyarakat Sulawesi Selatan harus sejalan dengan syariat Islam. Dalam konteks inilah, orang-orang yang memiliki pengetahuan tinggi tentang syariat Islam menempati posisi penting dalam kehidupan masyarakat. Bahkan, orang-orang tersebut diberi jabatan berupa Parewa Sara' (pejabat syariat) yang tingkatannya sama dengan Parewa Ade' dalam struktur kerajaan. Lebih jauh, orang-orang yang ahli dalam syariat Islam ini juga banyak diangkat di kerajaan pusat, yang disebut sebagai qadhi, pendamping dan pemberi nasehat kepada raja perihal keagamaan. Qadhi tersebut dibantu oleh para Imam, inilah yang membuat Imam menempati posisi penting bagi masyarakat. Mereka yang menjadi qadhi dan imam diakui sebagai orang-orang yang saleh serta memiliki pengetahuan agama yang sangat tinggi (Ilham, 2017). Dengan demikian, para qadhi dan Imam tersebut menjadi bagian penting dalam proses Islamisasi sekaligus penyebaran pemahaman Islam pada masyarakat Sulawesi Selatan.

Pada perkembangannya, para ulama diberi keleluasaan untuk menyebarkan agama Islam, termasuk dalam bentuk pendidikan. Dari sini, di kerajaan Gowa muncul Madrasah Islamiyah yang digagas oleh Imangimangi Daeng Matuju Karaeng Bontonompo Sultan Muhammad Tahir Muhibuddin (1936-1946). Termasuk di sini adalah kerajaan Wajo, yang memperluas 
dan menyempurnakan Masjid Jami' Tosora agar mendorong penyebaran dan pendidikan Islam. Selanjutnya, dalam catatan Ilham dikatakan bahwa (Ilham, 2017):

Ketika La Oddang Datu Larompong, Arung Matoa Wajo ke-47, memerintah Wajo dari tahun 1926-1933, beliau memiliki pengetahuan agama yang dalam. Karena sejak kecil dia dididik orang tuanya dalam masalah keagamaan. Ia sering bergaul dengan para ulama seperti, Haji Makkatu, seorang ulama yang sangat tegas dalam memberantas segala kemungkaran dan merintis pengajian yang bersifat klasikal di Tosora. Beliau juga dekat juga dengan AlBugisi (yakni AGH. Muhammad Al-Bugisy). Demikian juga di Kerajaan Bone, atas bantuan Petta Mangkau Bone, Andi Mappanyukki, pada tahun 1929 didirikan sebuah madrasah yang diberi nama "Madrasah Amirah" di Watampone. Pada 1935, pimpinan Madrasah beralih ke tangan Syekh Abdul Hamid al-Mishrî dan selanjutnya digantikan Syekh Mahmud alJawad bekas Mufti Madinah Al-Munawarah yang sebelumnya pernah mengajar di MAI Sengkang bersama Al-Bugisi.

Sampai di sini, proses Islamisasi di atas menunjukkan proses yang panjang, dari yang semula Islamisasi dilakukan oleh kerajaan, hingga diberikannya wewenang bagi orang-orang yang memiliki pengetahuan mendalam tentang syariat Islam. Di sini, ada dua point penting yang dapat dikaitkan antara Islamisasi di Sulawesi Selatan dengan kehadiran Pondok Pesantren As'adiyah. Pertama, kedudukan AGH. Muhammad Al-As'ad menempati peran penting selama Islamisasi di Sulawesi Selatan, terutama di abad $20 \mathrm{M}$. Hal ini secara khusus, AGH. Muhammad As'ad kerap mendapat peran penting sekaligus rujukan serta panutan selama proses Islamisasi berlangsung, sebagaimana tergambar di atas. Kedua, sejak awal ulamaulama As'adiyah memiliki kedudukan penting dalam proses Islamisasi di Sulawesi Selatan, terutama menjadi qadi dan imam. Hal ini karena banyak dari ulama As'adiyah yang menjadi qadi dan imam di wilayah Sulawesi Selatan, terutama daerah Bugis. Misalnya, AGH. Daud Ismail, yaitu murid sekaligus penerus AGH. Muhammad As'ad dalam memimpin MAI-As'adiyah, berhasil menjadi Imam Besar di Masjid Raya Lalabata Soppeng pada tahun 1943. Pada tahun 1966-2006, AGH. Daud Ismail menjadi qadhi di Bone (Ruslan dkk, 1975). Selain itu, AGH. Muhammad Yunus Maratan, juga murid AGH. Muhammad As'ad sekaligus piminan Pesantren As'adiyah, juga pernah memegang jabatan sebagai qadhi di wilayah Kabupaten Bellawa, tepatnya pada tahun 1938-1952 (Abunawas dan Ilyas, 2017). Dan ulama atau kiai Pesantren As'adiyah lainnya yang memiliki kedudukan penting bagi masyarakat, yang menunjukkan perannya dalam Islamisasi di Sulawesi Selatan seperti pimpinan pesantren, Imam Masjid, pendamping raja.

Seiring perkembangannya, terutama semenjak adanya program Mah'ad Aly sebagai sarana pengkaderan ulama, gerakan dakwah dalam kerangka Islamisasi di Sulawesi Selatan semakin marak dan gencar dilakukan, bahkan meluas ke berbagai wilayah Indonesia Timur. Dasmarianti, pendakwah bergelar kiai muda sekaligus pembina di Ma'had Aly Pondok Pesantren As'adiyah Sengkang, mengatakan bahwa program dakwah As'adiyah telah menjangkau daerah-daerah terpencil. Bahkan seiring perkembangan media sosial, banyak kiai muda juga ikut menyiarkan dakwahnya melalui media-media sosial seperti Youtube (@As'adiyah Channel) dan Facebook (@As'adiyah Pusat) (Wawancara bersama Dasmarianti, 04 Agustus 2021). Dengan kata lain, gerakan dakwah kiai muda mengalami perkembangan yang signifikan dan mengikuti perkembangan zaman. Meski demikian, Afikatul Aswan, pendakwah bergelar kiai muda sekaligus pengajar di MTs SA. Nurul Ulum As'adiyah Maroangin, menilai bahwa program dakwah ini masih perlu dikembangkan dan digencarkan, terutama untuk tidak hanya mengandalkan adanya permintaan atau undangan dari masyarakat baru dapat aktif berdakwah (Wawancara bersama Aswan, 04 
Agustus 2021). Pandangan Afikatul Aswan ini mengindikasikan bahwa sebaran kiai muda berkaitan erat adanya permintaan dari masyarakat, dari daerah manapun. Dengan pemahaman seperti ini, secara sadar masyarakat tersebut menghendaki model penerapan Islam dan Islamisasi khas As'adiyah.

Pada masyarakat tertentu, terutama yang telah akrab dengan tradisi Pesantren As'adiyah, seorang pendakwah yang bergelar kiai muda mendapat kedudukan yang lebih tinggi daripada pendakwah dengan gelar pendidikan formal pada umumnya, bahkan sekalipun tingkat doktor. Dalam pandangan Marlinda, pendakwah bergelar kiai muda sekaligus pembina Ma'had Aly Pondok Pesantren As'adiyah Sengkang, mengatakan bahwa masyarakat lebih mengutamakan da'i (pendakwah) yang berstatus mahasantri karena mereka menilai bahwa ada berkah tersendiri yang dimiliki sebagai alumni Ma'had Aly (Wawancara bersama Marlinda, 04 Agustus 2021). Kedudukan kiai muda yang lebih signifikan dalam masyarakat terlihat pada jawaban wawancara dari Abdullah Mangu, pendakwah bergelar kiai muda sekaligus pembina di cabang Pondok Pesantren As'adiyah Dapoko Bantaeng, yang mengatakan sebagai berikut:

Iya, sangat berpengaruh kebanyakan masyarakat menganggap kiai muda adalah sosok yang sangat paham agama bukan hanya karena ceramahnya yang menggugah. Bahkan masyarakat menganggap kiai muda adalah seorang yang alim dalam agama sehingga kiai muda dijadikan tempat bertanya segala problematika ibadah bahkan dalam problematika kehidupan sehari-hari (Wawancara bersama Mangu, 04 Agustus 2021).

Dengan bermodalkan gelar kiai muda tersebut, proses dakwah Islamisasi yang dilakukan oleh kiai-kiai muda dari Pondok Pesantren As'adiyah cenderung dapat berjalan mulus dan diterima oleh masyarakat setempat. Hal ini diperkuat oleh respon masyarakat-masyarakat terhadap dakwah-dakwah yang disebarkan oleh kiai muda tersebut. Yahya, seorang imam masjid di Desa Barugae-Bone, meyakini bahwa dakwah-dakwah yang didakwahkan oleh kiai As'adiyah adalah sesuai kebutuhan masyarakat Desa Barugae (Wawancara bersama Yahya, 04 Agustus 2021). Sejalan dengan ini, para kiai muda seperti yang diutarakan oleh Dasmarianti, Afikah Aswan, dan Abdullah Mangu merasa bahwa respon masyarakat terbilang menerima dengan baik. Bahkan atas dakwah yang mereka lakukan, tidak sedikit masyarakat mengagumi mereka sehingga memasukkan anak-anak mereka ke Pondok Pesantren As'adiyah, sebagaimana yang dikatakan oleh Marlinda. Dengan demikian, penyebaran model penerapan Islam dan Islamisasi khas As'adiyah menjadi bagian penting dalam gambaran masyarakat Islam di Indonesia Timur.

\section{Kesimpulan}

Dari berbagai paparan sebelumnya dapat ditarik kesimpulan bahwa Pesantren As'adiyah memiliki paham keagamaan Ahlu Sunna wal Jama'ah bermazhab Syafi'i, yang merujuk pada Imam Nawawi. Paham Ahlu Sunna wal Jama'ah dan mazhab Syafi'i khas As'adiyah senantiasa dijaga sekaligus disebarkan sejak masa AGH. Muhammad As'ad Al-Bugisi hingga kiai-kiai muda Pesantren As'adiyah program kaderisasi ulama pada jenjang Ma'had Aly. Lebih jauh, paham dan mazhab tersebut tidak hanya dipelajari tetapi diamalkan, baik pada lingkungan pesantren maupun ketika disebarkan dalam bentuk dakwah kepada masyarakat luas. Dari model penerapan Islam paham Ahlu Sunna wal Jama'ah dan mazhab syafi'i tersebutlah sehingga dakwah khas As'adiyah diterima dengan baik oleh masyarakat Indonesia Timur, baik era sebelum program kaderisasi ulama $\left(M a^{\prime} h a d\right.$ Aly) maupun pada masanya. Penerimaan masyarakat Indonesia Timur atas paham dan mazhab khas As'adiyah ini terbukti dari bertahan dan berkembangnya penerimaan masyarakat atas dakwah-dakwah yang disampaikan oleh kiai muda sebagai penghubung pemahaman dari kiai pimpinan dan pengasuh pesantrennya. 
Dengan demikian, kiai muda merupakan elemen penting dalam model penerapan Islam dan Islamisasi khas As'adiyah, sebagaimana peran penting imam masjid, qadhi, dan ulama bagi masyarakat dalam menyebarkan model penerapan Islam dan Islamisasi di Indonesia Timur. Karena itu, dalam rangka menjaga dan menyebarkan model penerapan Islam yang Ahlu Sunna wal Jama'ah dan bermazhab Syafi'i di Indonesia Timur, maka gerakan dakwah kiai muda perlu didukung dan dikembangkan.

\section{Ucapan Terima Kasih}

Penulis menyampaikan terima kasih kepada berbagai pihak Pondok Pesantren As'adiyah seperti kiai muda Ilham Nur yang bersedia menjadi perantara penulis dalam menelusuri dan mengkaji isu kiai muda di Pesantren As'adiyah. Terima kasih juga kepada para kiai muda yang bersedia menjadi informan dalam penelitian ini.[]

\section{Daftar Pustaka}

Abunawas, Ahmad Kamal Kamaluddin. (2019). Pelaksanaan Pengajian Halaqah dalam Pemahaman Keagamaan pada Ma'had Aly Pondok Pesantren As'adiyah Sengkang Kabupaten Wajo. Al-Qodiri: Jurnal Pendidikan, Sosial dan Keagamaan, Volume 17, Nomor 2.

Abunawas, Kamaluddin dan Husnul Fahimah Ilyas. (2017). Menguak Cakrawala Perubahan; Kiprah AGH. M. Yunus Martan dan AGH. Abdullah Maratan. Yogyakarta: Trusmedia Grafika.

Aguswandi. (2018). Kontribusi AGH. Muhammad As'ad terhadap Pengembangan Dakwah di Sengkang Kabupaten Wajo (Suatu Kajian Tokoh Dakwah). Jurnal Al-Khitabah, Volume. V, Nomor. 2.

Ahmad, Abdul Kadir. (2012). Buginese Ulama. Jakarta: Badan Litbang dan Diklat Kementrian Agama RI.

Akhmar, Andi Muhammad. (2018). Islamisasi Bugis: Kajian Sastra atas La
Galigo versi Bottinna I La Dewata Sibawa I We Attaweq (BDA). Jakarta: Pustaka Obor.

Al-Bone, Abdul Aziz. (1994). Transformasi Kelekturan Pesantren di Sulawesi Selatan. Ujung Pandang: Balai Penelitian Lektur Keagamaan.

Al-Bugisi, Al-Hajj Muhammad As'ad. (1355 H). Ma La Yasa Al-Muslim Jahlahu min Al-Aqaid Ahl al-Sunna wa Al-Jama'ah. Sengkang: tp.

Arief, Syamsuddin. (2007). Jaringan Pesantren Sulawesi Selatan 1928-2005." Disertasi UIN Syarif Hidayatullah, Jakarta.

As'ad, Muhammad. (2009). Pondok Pesantren As'adiyah. Jurnal Al-Qalam, Volume 15, Nomor 24.

Azra, Azyumardi. (1998). Jaringan Ulama Timur Tengah dan Kepulauan Nusantara Abad ke-XVII dan XVIII. Bandung: Mizan.

Dhofier, Zamakhsari. (2011). Tradisi Pesantren: Studi Tentang Pandangan Hidup Kiai dan Visinya Mengenai Masa Depan Indonesia. Jakarta: LP3ES.

. (1982). Tradisi Pesantren. Jakarta: Sinar Harapan.

Fathurrahman, Oman. (2004). Tradisi Intelektual Islam Melayu-Indonesia: Adaptasi dan Pembaharuan: Book Review Peter Riddel, Islam and the Malay-Indonesia World, (Singapure: Horizon Books, 2001). Jurnal Studia Islamika, Vol. 8, No. 3.

Halim, Wahyuddin. (2015). As'adiyah Traditions: the Construction and Reproduction of Religious Authority in Contemporary South Sulawesi. A Thesis Submitted for the Degree of Doctor of Philosophy. Australian National University.

(2021), The Reproduction of Imams and Their Changing Roles within the Contemporary Muslim Community in Wajo, South Sulawesi, Indonesia. 
Dalam Robinson, Kathryn M. (ed). Mosques and Imams: Everyday Islam in Eastern Indonesia. Singapore: NUS Press, National University of Singapore.

Hamdan. (2020). Pesantren dan Misi Perdamaian: Telaah Reposisi Pesantren pada Abad 21. Dalam Muhammad Sofi Mubarok dkk (editor), Prosiding Muktamar Pemikiran Santri Nusantara 2019 "Santri Mendunia: Tradisi, Eksistensi, dan Perdamaian Global". Jakarta: Direktorat Pendidikan Diniyah dan Pondok Pesantren, Direktorat Jenderal Pendidikan Islam, Kementrian Agama RI.

HS, Muh. Alwi. (2019). Pesantren dan Fenomena Islam Nusantara: Upaya Beragama Yang Moderat. Dalam Muhammad Yahya dkk (ed), Prosiding Muktamar Pemikiran Islam Nusantara 2018: Islam, Kearifan Lokal dan Tantangan Kontemporer. Jakarta: Direktorat Pendidikan Diniyah dan Pondok Pesantren, Direktorat Jenderal Pendidikan Islam, Kementerian Agama RI.

http://ditpdpontren.kemenag.go.id/pdpp/ statistik diakses pada 29 Januari 2021.

https://asadiyahpusat.org/2013/09/19/ sejarah-asadiyah/, diakses pada 28 Desember 2020.

https://asadiyahpusat.org/pendidikan/ mahad-aly/ diakses pada 02 Agustus 2021.

Idham. (2017). Pola Pengkaderan Ulama di Sulawesi Selatan (Studi pada Program Ma'had Aly Pondok Pesantren As'adiyah Sengkang Kabupaten Wajo). Al-Ulum, volume 17, Nomor 2.

Ilham. (2017). Konsep Pendidikan Kader Ulama Anregurutta Muhammad As'ad. Disertasi Universitas Ibn Khaldun Bogor.

Ilyas, Husnul Fahima. (2020). Anregurutta H.M. Yunus Maratan: the Figure of Reformer. Al-Qalam, Vol. 16, No. 2.
Ismail, Fatah. (2002). Dinamika Pesantren dan Madrasah. Yogyakarta: Pustaka Pelajar.

Kalsum, Ummu. (2008). KH. Muhammad As'ad Pendiri Pondok Pesantren As'adiyah Sengkang. Makassar: Alauddin Press.

Muchsin, Agus. (2016). Penerapan Manhaj terhadap Penguatan Fikih Kaderisasi Ulama Pondok Pesantren As'adiyah Sengkang. Jurnal Hukum Diktum, Volume 14, Nomor 2.

Muhajad, Ayyub. (2019). Peran Santri dalam Tantangan Kontemporer di Nusantara: Telaah terhadap Pondok Pesantren As'adiyah Sengkang Sulawesi Selatan sebagai Distributor Mubaligh Terbesar di Indonesia Timur. Dalam Muhammad Sofi Mubarok dkk (editor), Prosiding Muktamar Pemikiran Santri Nusantara 2019 "Santri Mendunia: Tradisi, Eksistensi, dan Perdamaian Global". Jakarta: Direktorat Pendidikan Diniyah dan Pondok Pesantren, Direktorat Jenderal Pendidikan Islam, Kementrian Agama RI.

Muhammad, Firdaus. (2017). Anregurutta: Literasi Ulama Sulselbar. Makassar: Nala Cipta Litera.

Muktamar, Ahmad dkk. (2019). Leadership K.H.M. Yunus Martan in Developing As'adiyah Boarding School (19611986). International Journal of Social Sciences, Vol. 74, No. 1.

Parninsih, Iin (2020). Metodologi Pembelajaran Anregurutta $\mathrm{H}$. Muhammad As'ad Al-Bugisi dalam Meneguhkan Islam Washatiyah di Wilayah Indonesia Timur. Dalam Muhammad Sofi Mubarok dkk (editor), Prosiding Muktamar Pemikiran Santri Nusantara 2019 "Santri Mendunia: Tradisi, Eksistensi, dan Perdamaian Global". Jakarta: Direktorat Pendidikan Diniyah dan Pondok Pesantren, Direktorat Jenderal Pendidikan Islam, Kementrian Agama RI. 
Pasanreseng, Muh. Yunus. (1992). Sejarah Lahir dan Pertumbuhan Pondok Pesantren As'adiyah Sengkang. Sengkang: PB. As'adiyah.

Pribadi, Yanwar. (2018). Islam, State and Society: Local Politics in Madura. New York: Routledge.

Robinson, Kathryn M. (ed). (2021). Mosques and Imams: Everyday Islam in Eastern Indonesia. Singapore: NUS Press, National University of Singapore.

Ruslan, Muhammad dkk (ed). (1975). Ulama Sulawesi Selatan: Sejarah Pemikiran dan Gerakan. Jakarta: Bulan Bintang.

Sabit, M. (2015). Dakwah Moderasi Anregurutta KH. Muhammad As'ad AlBugisi. Sengkang: Lempena Intimedia. (2012). Gerakan Dakwah H. Muhammad As'ad Al-Bugisi. Disertasi, UIN Alauddin Makassar.

Sila, Muhammad Adlin. (2019). Kiai dan Blater: Antara Kesalehan dan Kekerasan dalam Dinamika Politik Lokal di Madura. Studia Islamika, Vol. 26, No. 1.

Wawancara bersama Kiai Muda Ilham Nur, Sengkang, pada 23 Desember 2020.

Wawancara bersama Yahya, Barugae-Bone, pada 13 Mei 2021.

Wawancara via WhatsApp bersama Abdullah Mangu, pendakwah bergelar kiai muda (KM) sekaligus Pembina di Ma'had Aly Pondok Pesantren As'adiyah Sengkang, pada 04 Agustus 2021.

Wawancara via WhatsApp bersama Abdullah Mangu, pendakwah bergelar kiai muda (KM) sekaligus Pembina di Ma'had Aly Pondok Pesantren As'adiyah Sengkang, pada 04 Agustus 2021.

Wawancara via WhatsApp bersama Afikatul Aswan, pendakwah bergelar kiai muda (KM) sekaligus Pengajar di MTs SA. Nurul Ulum As'adiyah Maroangin, pada 04 Agustus 2021.
Wawancara via WhatsApp bersama Afikatul Aswan, pendakwah bergelar kiai muda (KM) sekaligus Pengajar di MTs SA. Nurul Ulum As'adiyah Maroangin, pada 04 Agustus 2021.

Wawancara via WhatsApp bersama Dasmarianti, pendakwah bergelar kiai muda (KM) sekaligus Pembina di Ma'had Aly Pondok Pesantren As'adiyah Sengkang, pada 04 Agustus 2021.

Wawancara via WhatsApp bersama Dasmarianti, pendakwah bergelar kiai muda (KM) sekaligus Pembina di Ma'had Aly Pondok Pesantren As'adiyah Sengkang, pada 04 Agustus 2021.

Wawancara via WhatsApp bersama Marlinda, pendakwah bergelar kiai muda (KM) sekaligus Pembina di Ma'had Aly Pondok Pesantren As'adiyah Sengkang, pada 04 Agustus 2021.

Wawancara via WhatsApp bersama Marlinda, pendakwah bergelar kiai muda (KM) sekaligus Pembina di Ma'had Aly Pondok Pesantren As'adiyah Sengkang, pada 04 Agustus 2021.

Wawancara via WhatsApp bersama Muhammad Iksan Ishak, pendakwah bergelar kiai muda (KM) sekaligus Pembina di cabang Pondok Pensantren As'adiyah Dapoko Bantaeng, pada 04 Agustus 2021.

Ziemek, Manfred. (1986) Pesantren dalam Perubahan Sosial. Jakarta: Perhimpunan Pengembangan Pesantren dan Masyarakat (P3M). 